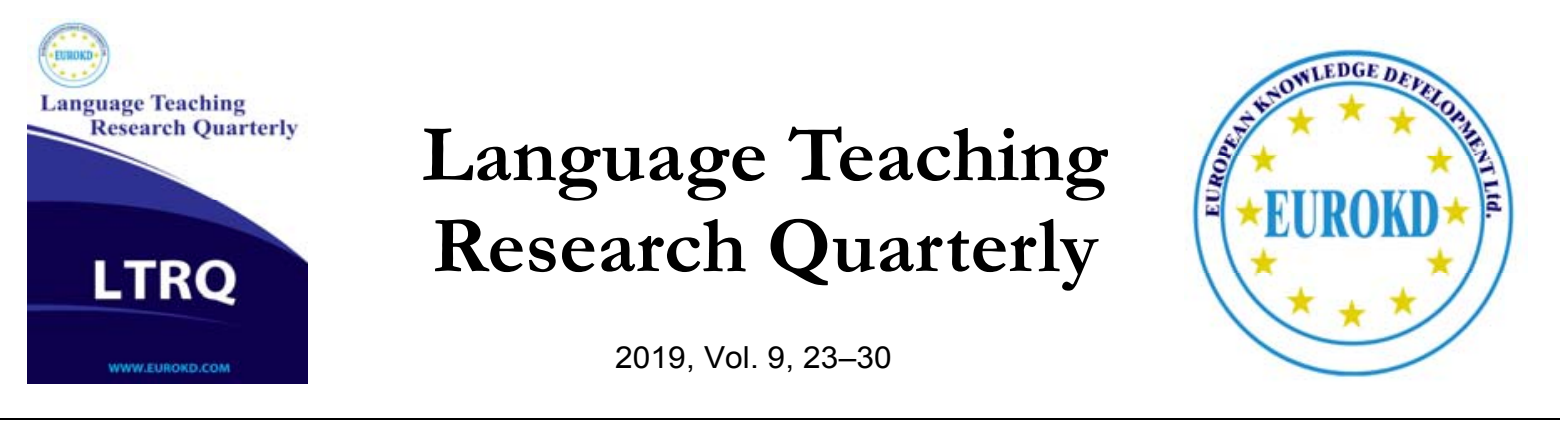

\title{
The Effect of Multiple Intelligences on Language Achievement of Iranian EFL Learners
}

\author{
Farnaz Sahebkheir \\ Department of English Language Teaching, Tabriz Branch, Islamic Azad University, Tabriz, Iran
}

Received 11 September 2018 Accepted 15 January 2019

\begin{abstract}
Applying Multiple Intelligences Theory in lessons is a new teaching activity which makes learning more attractive and effective. Since every person has their own abilities and intelligences, teachers should be aware of these talents and skills in their students and contribute them in their teaching process. For conducting this study forty learners were divided as two male and female learners. Their homogeneity was assessed through a TOEFL test. In this paper, the researcher emphasized various intelligences and assessed learners MI through completing a questionnaire. The results show that female learners have higher multiple intelligences. Furthermore, female learners outperformed male learners in the final writing test. According to the results, there is a positive correlation between MI and writing skill. This study proves that teachers should pay attention to MI and try to apply them in their teaching methods.
\end{abstract}

Keywords: EFL, Language Achievement, Multiple Intelligences, Writing Skill

\section{Introduction}

According to Gardner (1983), the intelligences do not develop on their own; they are justified and modified through different experiences. Teachers, peers, and text books usually have a basic role in strengthening these intelligences. Since lots of students with different levels of intelligences attend to a classroom, a good text book has a significant role in referring to as much intelligence as possible in order to cover students' needs and curriculum objectives. Individual intelligence is the combination of capabilities in different areas. Multiple intelligences (MI) 
theory has become very popular as it meets the global trend of making students the center of the educational systems. As learners are the most important element of any educational system, dealing with them should not be random. Their needs, learning styles, strengths and weakness should be addressed and recognized in order to have effective and meaningful learning. MI is a new model of learning that helps students to learn effectively. It also can affect students' behavior in schools as it makes them more involved by recognizing their needs which make them less frustrated and confused (Armstrong, 1994).

Multiple intelligences model also help students to recognize their own strengths and weakness so they know which way of learning is better for them and develop the weakness they have (Nicholson, 1999). In Spite of the spread of multiple intelligences model, it is not implemented in the Iranian context appropriately. One reason might be because of that all MI indicators being used are not suitable for the Iranian culture or even teachers are unfamiliar with these strategies. As a result of using MI, students are labeled as good or weak according to their marks. Some students are labeled as weak students, even if they have distinguished ability in other areas.

Every individual is born with these capabilities in their daily life. However, one or more of them can be more predominant over others (Akpınar, 2012). The theory of multiple intelligences mentioned by Gardner (1983) claims that every individual's level of intelligence is shaped by autonomous powers and capabilities, and also claims that every child has potential intelligence in one or more areas. Gardner believes that intelligence is not a simple mixture of only one area, but also a guide to the success in music, sport, paint, self-awareness and assessment. According to Gardner (2010), intelligence is an ability which solves problems and gains results within one or more cultural structures. It is also important to know that these areas are connected and supports each other. There is a strong relation between student's intelligence areas.

According to the recent researches done in education field, in order to have an effective educational process it is essential to recognize intelligence areas and know which parameters have an impact in identifying these areas. The basic reason to have such researches is to enable educators, who want to educate successful students and to understand which intelligence areas their students have. In addition, to examine from the perspective of the variables that may have an effect over intelligence areas. There are lots of research on the notion of multiple intelligences such as (Abbasian \& Khajavi, 2011; Nasiri, Ketabi, \& Dastjerdi, 2012; Kirkgoz, 2010).

Multiple Intelligences have been subject to a debate among psychologists. Psychologists have referred to intelligence as a joint of different skills and talents. According to Spearman (1927) intelligence (g-factor), is a general cognitive ability that could be measured and numerically expressed through an IQ. Oller (1978) connected the concept of intelligence to language, establishing that Spearman's "g" and language proficiency were virtually equivalent. Oller believes that What IQ tests actually measured was L1 proficiency. He considered Intelligence as linguistic level and, thus, an acquired ability or construct. Carroll (1997) claimed that although the correlation of general intelligence " $\mathrm{g}$ " with verbal ability would be high; mental development could also be expressed in other ways not related to language. Thurstone (1938) stated that intelligence was the sum of seven different primary mental abilities: verbal comprehension, 
reasoning, perceptual speed, numerical ability, word fluency, associative memory and spatial visualization. Gardner (1993) considered intelligence as the combination of different talents, influenced partly by genetics and partly by the culture in which a person has grown up. Oller (1978) claimed that human beings have eight types of intelligences classified as naturalistic, interpersonal, logical mathematical, visual-spatial, intrapersonal, bodily-kinesthetic, musicalrhythmic, verbal-linguistic and existential. Armstrong (1999) claimed that none of them was superior to the others and each could be autonomous, changeable, and trainable. Gardner (1993) defined the different types of intelligences as having the following characteristics:

1. Naturalistic intelligence: People with a remarkable Naturalistic intelligence will easily learn how to distinguish, classify and use the elements of the environment. They will observe, experiment, reflect and make questions. Doctors, veterinarians, and zoologists for example, will show this type of intelligence.

2. Interpersonal intelligence: This intelligence has to do with the ability to understand other people's feelings and the sensibility to capture even what is not said like gestures or manners. Therapists, mediators, leaders, politicians, educators, sales-people, psychologists and coaches will have a highly developed interpersonal intelligence.

3. Logical-mathematical intelligence: It consists mainly in the capacity to analyze problems logically, carry out mathematical operations and investigate issues scientifically. In Gardner's (1983) words “it entails the ability to detect patterns, reason deductively and think logically". This intelligence is most often associated with scientific and mathematical thinking and scientists, engineers, computer experts, researchers and bankers are good examples of logical - mathematical intelligence.

4. Visual-spatial intelligence: This type of intelligence includes the ability to interpret and create visual images, to understand relationships between images and meanings, and between space and effect. Designers, architects, photographers, sculptors and inventors need this type of intelligence.

5. Intrapersonal intelligence: Intrapersonal intelligence is directly related to the capacity of reflection and analysis about one's feelings, to the faculty of constructing an accurate image of oneself, organizing and ruling one's life based on it.

6. Bodily-kinesthetic intelligence: It is shown in the ability to perform coordinated corporal movements; the skill of using the body to express feelings or ideas. It is the ability shown by people who are able to use their hands to transform elements with precision: dancers, actors, athletes, osteopaths, crafts-people, chefs and surgeons.

7. Musical-rhythmic intelligence: It is the faculty of perceiving, distinguishing, transforming and expressing musical forms. Musical intelligence comprehends the ability to play, compose and appreciate musical language as well as the recognition of tonal and rhythmic patterns. Musicians, singers and composers present high rates of this type of intelligence. 
8. Verbal-linguistic intelligence: It includes the abilities to manage the spoken and written language, to use words effectively in order to reach a certain purpose. Writers, lawyers, journalists, teachers, translators or linguists would be some of the social roles associated to it.

New researches have shown the positive relation between Multiple intelligences and language achievement (e.g., Alizadeh, Saeidi, \& Hadidi, 2016; Dung \& Tuan, 2011; Paula Petru, 2013). Some other researches have shown that there isn't any relation between MI and Language achievements (e.g., Razmjoo, 2008; Sadeghi \& Farzizadeh, 2012). In order to conduct this study, the following questions were used:

1. Is there any significant relationship between female and male EFL learners' multiple intelligences and the quality of their writing?

2. Is there any significant relationship between female and male learners MI?

3. Is there any significant relationship between female and male learners' writing skills?

\section{Method}

\section{Participants}

Forty students as two intact groups from Payame Noor University participated in this study. Learners majoring in TEFL were passing Writing course in Tabriz, Iran. For assessing the homogeneity of both groups a placement test was conducted. This test was adopted from a TOEFL test from https://www.ets.org/. Numbers of students were 50 at the beginning of the study. The total score of the placement test was out of 120 . Those students, who got 1 SD over or below the mean score, were chosen for the test. One group was for females and the other group was for male students. Their age range was between 14 and 28.

\section{Instrumentation}

To be ensure of the homogeneity of two groups, the standard Test of English as a Foreign Language (TOEFL) was used. It included three sections: Listening comprehension, Structure and Reading comprehension (see Appendix B). Those who got one standard deviation below and above the mean were selected out of 50 participants. There are several scales to analyze learner's Multiple Intelligences; the researcher used Multiple Intelligence Developmental Assessment Scale in https://mypersonality.info/test-mi/. It consisted of 80 Likert type questions with three options (rarely, sometimes, usually) to choose as an answer (see Appendix A). Final writing task was used to assess their writing achievement. Their writings were scored using the analytic scoring of Hughes' (2005) scale. 


\section{Procedure}

The students were told that they would be informed of the results and interpretations of the results of the study. Therefore, they tried their best to honestly answer the questions in the study. After assessing the groups' homogeneity, the participants were asked to complete the Multiple Intelligences questionnaire; the researcher used Multiple Intelligence Developmental Assessment Scale (MIDAS) scale in https://mypersonality.info/test-mi/. To validate this questionnaire in the Iranian context, the researcher discussed with two other English specialists. They considered the content of the questionnaire and found it suitable for Iranian EFL learners. In addition to be sure of the reliability of this questionnaire, it was piloted with a sample group of 13 students. Their answers were checked with a delayed test. According to the results of the test-retest, there was a high reliability correlation coefficient between the results. It proves the appropriateness of this questionnaire for Iranian EFL learners. They were also informed of the purpose of taking the test. All students used their cell phone or laptop and answered the questions online. The researcher prepared the Persian translation of every question to avoid any misunderstanding problem. They got the results online and took the screenshot of their results and shared it with the researcher's e-mail. At the end of the term, they received a writing task and their papers were scored according to the analytic method mentioned by Hughes (2005). Based on this scale, content, text organization, vocabulary, form and mechanics were assessed. They were scored from 1-6. Total score was gained by adding the score of each item.

\section{Design}

The design of the study was correlational. The variables of the study included Multiple Intelligences scores and writing performance scores. In this study, the participants' gender was a moderator variable.

\section{Results}

The t-test for male and female learners' placement test show that there isn't any significant difference between two groups $\mathrm{P}>0.05$.

Table 1

Descriptive Statistics and Independent Sample T-test of the Scores of the TOEFL Test

\begin{tabular}{lcccccccc}
\hline Group & N & Mean & SD & Sig.(2-tailed) & df & Sig & t & F \\
\hline Control-pre & 20 & 78.43 & 2.25 & 0.89 & 38 & 0.81 & 2.554 & 1.65 \\
\hline experimental & 20 & 71.21 & 2.87 & 0.87 & 37.12 & & & \\
\hline
\end{tabular}

The t-test for the writing scores showed that female students $(M=24.65)$ outperformed male students $(\mathrm{M}=22.89) \mathrm{p}<0.05$ in the final exam. In order to find out the relationship between overall MI and male and female learners' writing, a Pearson product moment Correlational analysis was made to evaluate the strength and direction of the relationship. 
Table 2

\begin{tabular}{|c|c|c|c|c|c|c|c|}
\hline & & writing & MI & & & writing & MI \\
\hline & $\begin{array}{l}\text { Pearson } \\
\text { Correlation }\end{array}$ & 1 & 0.58 & & $\begin{array}{l}\text { Pearson } \\
\text { Correlation }\end{array}$ & 1 & 0.87 \\
\hline \multirow[t]{3}{*}{$\begin{array}{c}\text { Male } \\
\text { Writing }\end{array}$} & Sig. (2-tailed) & & 0.005 & $\begin{array}{l}\text { Female } \\
\text { Writing }\end{array}$ & Sig. (2-tailed) & & 0.005 \\
\hline & $\mathrm{N}$ & 20 & 20 & & $\mathrm{~N}$ & 20 & 20 \\
\hline & $\begin{array}{l}\text { Pearson } \\
\text { Correlation }\end{array}$ & 0.58 & 1 & & $\begin{array}{l}\text { Pearson } \\
\text { Correlation }\end{array}$ & 0.87 & 1 \\
\hline \multirow[t]{2}{*}{ MI } & Sig. (2-tailed) & 0.005 & & MI & Sig. (2-tailed) & 0.005 & \\
\hline & $\mathrm{N}$ & 20 & 20 & & $\mathrm{~N}$ & 20 & 20 \\
\hline
\end{tabular}

The results of the analysis revealed that there is a positive relationship between MI and writing skill of both male and female leaners. This relationship is higher among female learners $r=0.87$, $\mathrm{p}<.05$.

Table 3

Descriptive statistics of MI Items between Male and Female Learners

\begin{tabular}{lcccccccc}
\hline & music & kinesthetic & logical & spatial & linguistic & interpersonal & intrapersonal & naturalistic \\
\hline female & $87.93 \%$ & $66.34 \%$ & $89.56 \%$ & $88.23 \%$ & $98.54 \%$ & $94.22 \%$ & $93.26 \%$ & $99.42 \%$ \\
\hline male & $77.91 \%$ & $67.98 \%$ & $92.34 \%$ & $85.63 \%$ & $95.13 \%$ & $90.56 \%$ & $98.45 \%$ & $90.56 \%$ \\
\hline
\end{tabular}

As Table3 shows female learners got higher MI except for Kinesthetic, intrapersonal and logical intelligences. In this study, the relationship between learners' Multiple Intelligences and their writing performance was investigated through correlational analyses. The results show that female learners have higher multiple intelligences. It has positive correlation with their written performance. This study is in line with the previous findings by (Alizadeh, Saeidi, \& Hadidi, 2016; Dung \& Tuan, 2011; Paula Petru, 2013).

\section{Discussion and Conclusion}

The verbal-linguistic intelligence is considered by Gardner "the most widely shared multiple intelligence items among human species"(Gardner, 1993, p.78). This type of intelligence may be used in speaking, listening and writing activities, such as group discussions, writing and other activities that occur in the classroom. According to Gardner (2006, p.23) bodily-kinesthetic intelligence entails the potential of using the body or parts of the body to solve problems, to create something, to express emotions. This type of intelligence can contain using drama, energizers, jigsaw puzzles, etc. They use body language to reinforce the verbal message. $\mathrm{He}$ 
further says that spatial intelligence is the potential to recognize and manipulate the patterns in spaces. These activities may involve representing information/experiences using charts, diagrams, mind maps; highlighting main ideas; watching video recordings/ movies, etc.

Gardner believes that "the musical talent emerges the earliest of all the gifts that individuals may be endowed with" (Gardner, 1993, p. 99). These multiple intelligences activities contain using audio recordings from classroom in order to identify the type of activity; using music to create a relaxed atmosphere before or even during the mentoring session.

The Interpersonal intelligence is recognized as activities like collaborative learning experiences; cooperative learning activities; group discussions on successful experiences, interviews with students, peers and teachers.

The intrapersonal intelligence permits the person to have access to his/ her feelings and emotions and to use them in order to understand and guide his/her behaviour (Gardner, 2006). There are many advantages of using Multiple Intelligences since they help the teachers to become more aware of their intellectual competences; they also become better observers of their students and thus able to personalize the teaching-learning process.

This study implies that teachers should pay attention to different intelligences in their learners and try to use them in their teaching method. There should be always different methods to teach students based on the type of intelligence they have. Having multiple intelligence profiles of students, will enable teacher to know their students, and understand their similarities and differences better. It can be concluded that Students' dominant intelligence areas must be taken in account when planning the education and the environments that education occurs in it. In this way, students will be encouraged to participate in educational process more actively. When students use their strengths, this will have a positive effect over other areas. There are number of researches showing that students' interests and intelligence areas are different based on gender. These natural features must be considered. By considering the differences based on students' variety, potential inequalities may be prevented. Giving students tasks in agreement with the areas that they are skilled at, will result in their personal developments. Considering the fact that students are the best authorities to judge their own abilities and differences, their personal development records must contain results of students' self-assessments. In future researches, the correlation between students' and teachers' opinion about students' skill area, can be examined. By doing so, more reliable and detailed data will be achieved.

The findings imply that MI could be used by school counselor in counseling process, and by researcher in developing knowledge on intelligence types. However, because of limited sample type, further research replicating the present study is required in future with larger and different samples for the multiple intelligence models to be generalized with different language proficiency and different language backgrounds. As a result, Using MI by teachers is highly recommended to address students' needs and abilities. I also recommend using it by parents to help them get an idea of their children's needs and abilities. Thus, the results of using MI can contribute very well to instruction design. 


\section{References}

Abbasian, R., \& Khajavi, Y. (2011). English language teaching program of universities: Does it cater for multiple intelligences of students. Porta Linguarum: revista internacional de didáctica de las lenguas extranjeras, 17 , 111-132.

Alizadeh, H., Saeidi, M., \& Hadidi N.T. (2016). The Relationship between Iranian EFL Learners' Multiple Intelligences and their Writing Performance across Different Genders. The Journal of Applied Linguistics, 7(14), $1-20$.

Akpınar, B. (2012). Ĕgitim Programlarıve Öğretim. Ankara: Data Yayınları.

Armstrong, T. (1994).Multiple Intelligences in the Classroom. Alexandria, Va.: ASCD.

Armstrong, T.(1999). Kinds of Smart: Identifying And Developing Your Multiple Intelligences.

New York, Plume.

Carroll, R. L. (1997). Patterns and processes of vertebrate evolution. Cambridge.

Dung, N. T., \& Tuan, L. T. (2011). Accommodating classroom activities to EFL learners' multiple intelligences. Mediterranean Journal of Social Sciences, 2 (1), 79-109.

Gardner, H. (1993). Multiple intelligences: The theory in practice. New York: Basic Books.

Gardner, H. (1983). Frames of Mind: The theory of Multiple Intelligences. New York, Basic Books.

Gardner, H. (2006). Inteligente multiple. Noi orizonturi. Sigma, Bucharest.

Kirkgoz, Y. (2010). Catering for multiple intelligences in locally-published ELT textbooks in Turkey, Procedia, 4(5), 127-130.

Nasiri, M., Ketabi, S., \& Dastjerdi, H. V. (2012), Multiple Intelligences in Locally-published ELT Textbooks in Iran, $M J A L$, 4(4), 112-119.

Nicholson-Nelson, K. (1999). Developing students' multiple intelligences. Scholastic: New York.

Paula Petru, G. (2013). Multiple intelligences stimulated within the lessons by the practicing students from the Faculty of Sciences. Procedia - Social and Behavioral Sciences, 76, 676 - 680.

Razmjoo, S. A., (2008). On the relationship between multiple intelligences and language success. The Reading Matrix, 8(2), 155-174.

Thurstone, L.L.(1983). Primary Mental Abilities. Chicago: University of Chicago Press; 1938. 